\section{Drug firm depressant}

The Labour Party last week unveiled its discussion document on state participation in Britain's pharmaceuticals industry. At least one argument adduced, concerning research, is likely to be disputed. Chris Sherwell reports

STRONG criticism of the level and direction of private sector pharmaceutical research and development in Britain, which is subsidised by the Department of Health and Social Security (DHSS), is contained in the Labour Party's consultative policy paper "Public Control of the Pharmaceutical Industry". The views form just one plank in the platform from which it argues that, in the public interest, the recently established National Enterprise Board should "as a matter of urgency" acquire "at least one" UK-owned company with a substantial interest in pharmaceuticals and use it as a base for expansion of the public sector within the industry. It also suggests that there should be "researchbased planning agreements" between domestic and foreign companies and the national health service to determine, among other things, the amount of research undertaken in Britain.

This amounts to a considerably watered-down version of the original Labour proposals for wholesale nationalisation of the industry. Indeed, the working group compiling the document now describes these proposals as "impractical". Even in their moderated form, though, the latest proposals quickly received a blanket condemnation from $\mathrm{Mr}$ Michael Peretz, President of the Association of the British Pharmaceutical Industry.

The research aspects of the argument appear to have a fairly pivotal role: as the 62-page document, which devotes a separate chapter to the subject, says, "the long run future of the pharmaceutical industry in Britain depends on the quality and quantity of its research and development"; the UK-based industry's "greatest asset", it adds, is its group of research scientists. Labour's overall argument for public sector control does not necessarily stand or fall on the case it presents in respect of research and development, of course. But if preliminary reactions expressed last week by researchers themselves are anything to go by, the four identifiable strands of that case do not do much to strengthen the overall argument.

The first, and perhaps most important, strand argues that, while the existing system of profit control encourages research expenditure, it is "impossible to be sure" that all such activity is socially useful. The working group says it is "gravely concerned" that key areas of research can be neglected; there is, it says, "a social case for government funding of research into remedies for conditions which are obscure or occur mainly in developing countries"; it is "open to question whether a wholly profit orientated industry always fully serves a social purpose in long term research".

Only one of the directors of research at industrial and privatelyfinanced research laboratories consulted last week expressed any sympathy with this view-and even he refused to allow himself to be less than $98 \%$ against the proposals on this count. Similarly, three professors could see little merit in the second strand, which anticipates the view that a mechanism already exists, through the research councils, for the government to sponsor research in areas where no commercial company would take the risks.

The working group says that even with the implementation of the customer-contractor principle, there has only been a "paper transfer of ongoing work"; there must be "changes of policy over research", not wasteful duplication of administration. The danger, it says, is that "priorities will continue as before". Only one respondent tended to agree with this, and then only because he thought the MRC was "in a mess anyway". But no respondent disputed that the mechanism was indeed there.

The Labour group's objections go further, however. It points out that any long term research effort sponsored by a government department in an area of strong social need would have to be carefully planned; but, it says, this might replicate the very divorce of long term research from industry which is currently a weakness. It admits that closer links could not be better achieved by a public sector company which was commercially orientated. But, and this is the third strand, a long term research effort sponsored by a public sector company would be "more defensible for the government", and might also make it "easier to establish closer structural links" between the DHSS. the research councils and the industry. Research staff might also prefer to work in a publicly-owned where profit-maximisation was not the only force guiding their work, it argues.

These suggestions also fell on stony ground because they seemed so much a matter of opinion. Cooperation already existed, Nature was told, and and more bureaucracy was not wanted. As for the final strand of the argument, concerning competition and duplication in research, there was no doubt that both were vital to progress, and in fact even the Labour group acknowledges the advantages without seriously challenging them.

Beyond the idea of closer cooperation between a publicly-owned sector and existing state-sponsored research the Labour group wants wide-ranging planning agreements and a "general system of indirect public accountability and control", the objective being "to change the balance of public and private power within the industry". $\square$

USA

\title{
Explosions treaty blasted
}

Colin Norman reports from Washington on the controversy blowing up over the latest US-USSR nuclear agreement

IN July 1974, Richard Nixon, then almost engulfed by Watergate, completed one of his last Presidential acts of international statesmanship - the signing of a US-USSR bilateral agreement outlawing the testing of nuclear weapons with yields greater than 150 kilotons. The treaty was greeted by arms control advocates in the USA with utter dismay. They regarded it as a meaningless gesture which would do little to dampen the arms race. Last month, that treaty was extended to cover so-called peaceful nuclear explosions and the reaction has been equally negative.

The Federation of American Scien- tists (FAS), a liberal organisation whose sponsors include a galaxy of scientific stars, has condemned the joint pact as "worse than nothing". And last week, two former high ranking government officials argued that the treaty is little more than a sham which could seriously impede efforts to prevent the proliferation of nuclear weapsons to countries which do not now possess them. Such powerful opposition could delay, or even scuttle, ratification of the treaty by the Senate. 